\title{
Online Digital Book as Learning Material in University
}

\author{
Hirnanda D. Pradana ${ }^{1, *}$ Andi Kristanto ${ }^{1}$ Utari Dewi ${ }^{1}$ \\ ${ }^{I}$ Departement of Educational Technology, Faculty of Education, Universitas Negeri Surabaya, Indonesia \\ *Corresponding author. Email: hirnanda@unesa.ac.id
}

\begin{abstract}
This development research aims to create online digital books that students can use at the university level. Development is carried out following the ADDIE development model, consisting of five stages: analysis, design, development, implementation, and evaluation. Validation is carried out with the assistance of material experts, media experts, and educational technology students. The initial data collection took place through interviews with lecturers and students at the Department of Educational Technology. During the analysis of needs, lecturers stated that they require online learning materials that students can use to understand better the materials, one of which is Digital Online Book. Media experts validated $86.0 \%$ of the results, while material experts validated $88.6 \%$ for an overall average of expert validation results of 87.9 per cent. Individual product trials yielded 86.0 per cent, small group trials yielded $84.0 \%$, and field trials yielded $88.0 \%$. The development and research concluded that the developed online digital book is feasible and valid for education. It demonstrates that developed online digital books are deserving of being used as instructional materials for students.
\end{abstract}

Keywords: Online digital book, Learning material, Educational technology.

\section{INTRODUCTION}

The learning process must be implemented competently in order to maximize the potential of students. Quality learning refers to the abundance of learning materials available and the creation of active and effective learning activities. The learning process is not conducted in a single direction but to engage students and make learning more meaningful. Studentcentred learning significantly impacts the development of knowledge and comprehension of the material being studied [1]. Learning materials should be designed and written following learning rules. That is, they should be adjusted for learning materials, organized according to learning needs, include evaluation materials, and be engaging for students to learn [2].

Learning media is a tool that is one component of the learning process that the teacher must plan for during instructional activities [3]. Learning media can be used to accomplish learning goals [4]. With the advancement of communication and technology and the discovery of the learning process's dynamics, the implementation of educational and teaching activities has become increasingly demanding, as has to obtain a diverse range of learning media [5]. An electronic book is a critical tool for learning because it is easily accessible and portable enough for students to carry around, reducing the number of items each child must transport to school [6].

Introduction to learning media is a required course for Educational Technology students. Introduction to Learning Media provides students with the initial capital necessary to participate in other subjects' learning. This is deemed necessary in order for students to acquire competencies in educational technology. Introduction to learning media is a course that places a premium on competence in educational media. This course shapes the character of educational technology students' competence as developers of learning media. The ability to develop learning technologies is one of the competencies required of graduates of educational technology programs. Online education allows for greater flexibility and encourages students to pursue independent learning [7]. In order to implement learning through the introduction of learning media, joyful learning resources are required to keep students from becoming bored and to motivate them to participate in learning activities.

The use of learning resources plays a critical role in resolving issues that arise during the learning process. To obtain learning resources, lecturers can utilize resources obtained from anywhere and in any format in order to provide information to students. Learning 
resources are inextricably linked to a variety of other activities and management processes, including strategic planning, management development, and organizational development. The relationship between these facets of management is so intimate that it's difficult for us to avoid discussing them separately [8]. Thus, lecturers are expected to be able to utilize, provide, and develop learning resources, beginning with those that are simple or already available and progressing to those that are technological in nature. This is done to provide learning tailored to students' needs and opportunities that are tailored to students' learning styles. Good learning material is adaptable to the needs of the student [9].

Indonesia was taken aback by a new outbreak dubbed Corona Virus Disease 2019 (Covid-19). The virus's epidemic has instilled widespread fear in the world's population. The virus, dubbed covid-19, was discovered in mid-December 2019 [10]. Suddenly, this virus altered the landscape of the world, including the educational system. This virus spreads at such a rapid rate that it affects a large number of people. To help contain the spread of the virus, the Indonesian government has instituted an indefinite school closure policy.

The education system in Indonesia must also adapt to current conditions. The Minister of Education and Culture of Indonesia issued notification letter number 4 of 2020, which details the implementation of educational decisions aimed at resolving the extremely urgent situation created by the rapid spread of the COVID-19 outbreak [11]. Schools will close or discontinue face-to-face instruction in favour of distance education in order to protect school residents from the COVID-19 outbreak. COVID-19 has the effect of prohibiting all human activity outside the home. This has a profound effect on every facet of life. The education sector is one of the sectors affected by the COVID-19 outbreak [12].

While distance learning may be novel for lecturers and students, the use of technology allows for continuous learning activities even while at home. Distance learning requires lecturers, students, and parents to make extensive use of technology. Lecturers should be more inventive in their use of learning resources to enhance the distance learning process, one of which can be accomplished by developing learning resources. This is reinforced by research findings that the learning process must be conducted effectively via online education [13].

According to the findings of interviews with lecturers and several Education Technology students involved in implementing distance learning, distance learning has a number of issues, one of which is the content of Introduction to Learning Media. With all of the constraints, constraints, and complications, lecturers are required to fully implement online learning with all of the complications that accompany it [14]. The issues that arise are that students become disinterested in learning. This is because collecting assignments from lecturers is monotonous, and students are less enthusiastic about learning from textbooks. The lecturer distributed assignments via WhatsApp Group, which resulted in minimal use of student textbooks and decreased student interest in textbook reading.

The difficulty students face with introductory learning media materials is that the material is difficult for students to understand due to limited learning resources or learning materials used by lecturers. Additionally, in learning activities, students complete assignments without first receiving an explanation of the material from the lecturer. As a result, students rely on "google" to complete the task, which is unfortunate because students do not understand the material well. Additionally, students believe that they are more interested in learning through interesting pictures and videos. Science and technology advancements, particularly in information technology, have a significant impact on the implementation of learning media. With this advancement, lecturers can utilize various media to meet specific needs and learning objectives, making the learning process more engaging [15]. Numerous factors contribute to the issues mentioned above, including lecturers' lack of awareness of the critical nature of learning resources created or used according to the needs of the learning process. Another issue is lecturers' inability to create or develop digital learning resources that can be accessed online. One of these efforts is to implement hybrid learning, online distance learning, to ensure that the student learning process runs smoothly and with the highest possible quality [16].

Based on the information gleaned from the research findings explained that distance learning cannot yet be called ideal learning because of the numerous obstacles that must be overcome during its implementation; in light of this, the government is attempting to overcome these obstacles through the preparation of lecturers, the expansion of communication networks, and the effective use of learning resources[17]. The developer deduces from this statement that one of them is the debriefing provided by the government to lecturers, which includes educating lecturers on the proper use of platforms, maximizing the use of technology, and utilizing a variety of different types of learning resources to aid in the learning process. The industrial revolution 4.0 era "compel[s]" education systems to develop technologyenhanced learning processes [18]

Lecturers' role as educators should be to program everything that can improve the quality of learning according to student needs by increasing self-ability and maximizing the use of software when implementing distance learning. To maximize the use of technology 
and design learning resources tailored to students' characteristics, lecturers can maximize the use of technology and design learning resources tailored to their characteristics [19]. It is necessary to determine the nature of the problem and devise a strategy for resolving it. A successful learning process can be implemented if backed up by effective learning resources, such as digital books. Online digital books are considered beneficial if their presentation is attractive and their use is simple, increasing students' interest in the book and their desire to read it.

One solution or method for resolving the problems described above is to develop an online digital book. Naturally, the developer modifies this digital book, making it unique from previous research. The digital book that will be developed will be attractively packaged to ensure that students are not bored while reading; it will contain material, images related to the material, instructional videos, practice questions, and skill activities. Students will experience the same sensation as reading a printed book when they switch pages due to the transition effect. Additionally, the digital book that will be developed is intended for use in introductory media education courses.

About effectively mastering media. The hope is that by developing online digital books, lecturers and students will be able to access them from any location and at any time, thereby facilitating the learning process, particularly in distance education. Additionally, it is hoped that it will enhance student comprehension through the reading of material, observation of images, and viewing of videos contained in online digital books, ensuring that the online learning process is not limited to assigning assignments but that students are also engaged in learning activities to enhance their comprehension.

\section{METHODS}

The research and development method used in this development is the ADDIE development model, which has five stages: analysis, design, development, implementation, and evaluation [20], [21]. The stages of development in the ADDIE model are extremely complex. The developer completes all stages of the ADDIE development model when creating an online digital book.

\subsection{Analysis}

The analysis section conducts a needs analysis, an audience analysis, a topic analysis, and a task analysis [22]. Development does this in great detail during the analysis stage. If this analysis stage is carried out thoroughly, the resulting product will align with the needs and resolve learning problems. The developer has described each component in detail, from lecturers to students, learning topics, and assignments.

\subsection{Design}

This design stage is where the product's design (online digital books) is planned. This design stage is where the developer will plan the project he is developing (development of a product). Numerous products fail or do not work due to the design not being mature or ready but being compelled to continue [9].

\subsection{Development}

The development stage involves the process of integrating technology, management, and educational processes. Developers have begun developing prototypes of online digital books at this stage. Additionally, instructional designers have begun developing and producing high-quality materials for this type of learning, beginning with the design, teaching materials, and learning process [20].

\subsection{Implementation}

The implementation stage is when the developed learning products are put into action [23]. The developer conducts three types of trials during the product implementation stage: individual trials, small group trials, and field trials. The developer collects feedback from students who use the online digital book during the trial phase.

\subsection{Evaluation}

The final stage is to conduct an evaluation, the results of which will indicate whether the product is valid or invalid [24]. Through questionnaires distributed to students, this stage of development examines the feasibility of online digital books. Making sense of the questionnaire results distributed to material experts and learning media experts is a stage of evaluation in the development process.

This research and development process involves a variety of respondents, including test subjects and endusers. Two experts will evaluate the developed online digital book, including material experts and media experts. Meanwhile, the users who responded to the survey or were selected for testing during this online digital book were students studying Education Technology. There are two data collection techniques that developers employ when creating online digital books: interviews and questionnaires. Interviews were conducted with lecturers and students to collect data during the research process, whereas questionnaires were used to collect data related to the developed product assessment process. 
The developer creates a questionnaire in the shape of a Likert scale and distributes it to respondents, assigning a rating or score to each alternative response based on the following provisions: [25]. The data collected from the respondents' responses to the questionnaire will be analyzed using quantitative descriptive data analysis techniques. The data analyzed were drawn from the responses of media experts, material experts, linguists, and students to questionnaires.

Table 1. Scoring criteria questionnaire assessment guidelines

\begin{tabular}{|l|l|}
\hline Criteria & Score \\
\hline Very Good & 4 \\
\hline Good & 3 \\
\hline Less Good & 2 \\
\hline Not Good & 1 \\
\hline
\end{tabular}

Using the following formula, determine the average score for material testing, language testing, media testing, and student responses to the use of digital books [25].

Persentage $=\frac{\text { Total score obtained }}{\text { Total maximum score per item }} \times 100 \%$

Following the average score calculation, the developer will use score interpretation to convert quantitative data to qualitative data: [26].

Table 2. Interpretation of eligibility score percentage criteria

\begin{tabular}{|l|l|}
\hline Percentage score range & Information \\
\hline $0 \%-25 \%$ & Not Good \\
\hline $26 \%-50 \%$ & Less Good \\
\hline $51 \%-75 \%$ & Good \\
\hline $76 \%-100 \%$ & Very Good \\
\hline
\end{tabular}

According to the feasibility score interpretation table, a percentage of criteria for developing online digital books is declared to meet the category if a score of $>50 \%$ with a "Good" statement or a score of $>75 \%$ with a "Very Good" statement is obtained.

\section{RESULTS AND DISCUSSION}

This development results in a product in an online digital book containing learning content for introductory learning media courses customized for Education Technology students. Because the product contains only educational media content, it is titled "Buku Digital Pengantar Media Pembelajaran" The development of online digital books followed the ADDIE model's stages.
The first stage is analysis, which involves interviewing lecturers and students about their experiences with learning content. Conduct a needs analysis to ascertain whether the lecturer believes the books provided are still ineffective for learning. That additional books are required to ensure that students understand the material well. Additionally, digital books have never been used in education, and lecturers believe that using them will aid in delivering material and provide students with a more readily accepted understanding. Thus, learning should be connected to the media that students encounter daily. Thirdly, through material analysis of the results of student interviews, it was determined that students struggled to distinguish between learning media and media used in learning. Additionally, students struggle to articulate the benefits or impacts of learning without or with media.

The second stage is design; developers compile material by collecting various sources in the form of books to be used as references in making digital books, compiling materials and adapting them to learning objectives. The developer saves the material used in the Word document, which is done to make it easier for the developer to edit the material designed in the Word document. Next, the developer determines various software that can be used to create online digital books. In addition, the design of the digital-book follows the flowchart that the developer has previously prepared. The following is the flowchart used in the development of online digital books.

The second stage designs, during which developers compile material by collecting various sources in the form of books to use as references when creating digital books, compiling and adapting materials to learning objectives. Following that, the developer researches various software applications for creating online digital books. The developer saves the material used in the Word document; this is done to make editing the Word document material easier. Additionally, the digital book's design adheres to the developer's previously created flowchart. The flowchart illustrates the process of developing online digital books.

The third stage is development, which begins with pre-production activities such as setting up and installing the necessary software on a laptop, transferring previously compiled material in a Word document to a program called Canva, determining the paper size to use, and creating instructional videos. The developer then validates the digital book with expert reviewers such as material experts and learning media experts during the Post-Production stage. The assessment or review results are used as a guide for revising the digital book to make it more feasible to implement.

The fourth stage is implementation, which occurs after the online digital book has been evaluated and 
refined by experts. Additionally, online digital books are implemented to reach Education Technology students. Distance learning was used to carry out the implementation activities, including a person trial involving three students, a small group trial involving nine students, and a field test trial involving forty students.

Evaluation is the fifth stage. The final stage of this development model is evaluation; at this stage, validation data from experts such as material experts and experts in learning media is collected. Additionally, it contains data from questionnaires administered to students. The following table summarizes expert test validity and the results of a student response questionnaire.

Table 3. Expert test validity

\begin{tabular}{|l|l|c|l|}
\hline \multicolumn{2}{|c|}{ Trial stage } & Result & Criteria \\
\hline \multirow{2}{*}{$\begin{array}{l}\text { Experts } \\
\text { test }\end{array}$} & $\begin{array}{l}\text { Material } \\
\text { experts }\end{array}$ & $88,6 \%$ & Very good \\
\cline { 2 - 4 } & $\begin{array}{l}\text { Learning } \\
\text { media } \\
\text { experts }\end{array}$ & $86,0 \%$ & Very good \\
\hline \multicolumn{2}{|c|}{ Average } & $87,3 \%$ & Very good \\
\hline
\end{tabular}

Based on the table above, it can be seen that digital books obtained an average result from material experts and learning media experts of $87.3 \%$ and were included in the very good criteria.

Table 4. Student response questionnaire data results

\begin{tabular}{|c|l|l|l|}
\hline No. & Respondent & Result & Criteria \\
\hline & Person & $86,0 \%$ & Very good \\
\hline 2 & Small group & $84,0 \%$ & Very good \\
\hline & Field test & $88,0 \%$ & Very good \\
\hline
\end{tabular}

Based on the table of student response questionnaire data above, it can be seen that the digital book has achieved very good criteria and can provide convenience for students to understand the material.

At this stage, the digital book has met extremely stringent criteria based on expert validation and student response questionnaire data results, leading the developer to conclude that the successfully developed product is suitable for use as an engaging learning resource that facilitates comprehension of learning media material.

\section{CONCLUSION}

This research and development outcome is a product in an online digital book for an introduction to media learning course. The resulting product is titled "Introduction to Learning Media" and is intended to be used as a learning resource. This development research entails examiner respondents, who include experts in learning media and material. At the same time, students serve as the user respondents in this development research. When creating an online digital book, the developer follows the ADDIE development model, consisting of five stages: analysis, design, development, implementation, and evaluation. This development and research conclude that the developed online digital book is feasible and useful for educational purposes.

\section{REFERENCES}

[1] H. D. Pradana and D. Kuswandi, "Model Learning Cycle Dalam Pengembangan," Pros. TEP \&PDs, pp. 292-297, 2017.

[2] K. Indrawari and S. Habiburrahman, "Pengembangan Bahan Ajar Pendidikan Agama Islam Menggunakan Metode al-Qur'an Tematik," Cendekia J. Kependidikan Dan Kemasyarakatan, vol. 17, no. 1, pp. 17-35, 2019, doi: 10.21154/cendekia.v17i1.1357.

[3] I. Gunawan and A. R. Paluti, "Premiere Educandum," E-Journal.Unipma, vol. 7, no. 1, pp. $1-8,2017$.

[4] S. Halijah, Susilo, and W. G. Mulawarman, "Menggunakan Model Kooperatif Round Table," Diglosia, vol. 3, no. 2, pp. 115-124, 2020.

[5] G. Amirullah and R. Hardinata, "Pengembangan Mobile Learning Bagi Pembelajaran," JKKP (Jurnal Kesejaht. Kel. dan Pendidikan), vol. 4, no. 02, pp. 97-101, 2017, doi: 10.21009/jkkp.042.07.

[6] J. Y. Chao, P. W. Tzeng, and H. Y. Po, "The study of problem solving process of e-book PBL course of Atayal senior high school students in Taiwan," Eurasia J. Math. Sci. Technol. Educ., vol. 13, no. 3, pp. 1001-1012, 2017, doi: 10.12973/eurasia.2017.00654a.

[7] A. Sadikin and A. Hamidah, "Pembelajaran Daring di Tengah Wabah Covid-19," Biodik, vol. 6, no. 2, pp. 109-119, 2020, doi: 10.22437/bio.v6i2.9759.

[8] A. Ikhwan, "Development of Educational Resources," Cendekia J. Kependidikan Dan Kemasyarakatan, vol. 18, no. 1, pp. 1-16, 2020.

[9] H. D. Pradana and D. Kuswandi, "Augmented Reality Learning Materials for Motion Picture Making Subject," vol. 6, no. 3, pp. 108-114, 2018.

[10] M. A. Shereen, S. Khan, A. Kazmi, N. Bashir, and R. Siddique, "COVID-19 infection: Emergence, transmission, and characteristics of human coronaviruses," J. Adv. Res., vol. 24, pp. 91-98, 2020, 
https://doi.org/10.1016/j.jare.2020.03.005.

[11] H. Wulandari and E. Purwanta, "Pencapaian Perkembangan Anak Usia Dini di Taman Kanakkanak selama Pembelajaran Daring di Masa Pandemi Covid-19," J. Obs. J. Pendidik. Anak Usia Dini, vol. 5, no. 1, pp. 452-462, 2021, doi: 10.31004/obsesi.v5i1.626.

[12] S. Erni, R. Vebrianto, C. R. Miski, Z. A. MZ, Martius, and M. Thahir, "Refleksi Proses Pembelajaran Guru MTs dimasa Pendemi Covid 19 di Pekanbaru: Dampak dan Solusi," J. Educ. Learn., vol. 1, no. 1, pp. 1-10, 2020.

[13] E. J. Sintema, "Effect of COVID-19 on the performance of grade 12 students: Implications for STEM education," Eurasia J. Math. Sci. Technol. Educ., vol. 16, no. 7, pp. 1-6, 2020, doi: 10.29333/EJMSTE/7893.

[14] E. N. Wahyuni, R. Aziz, W. Wargadinata, and A. Y. Efiyanti, "Investigation of Primary School Teacher Readiness in Online Learning during the Covid-19 Pandemic," Madrasah J. Pendidik. dan Pembelajaran Dasar, vol. 13, no. 2, pp. 97-113, 2021, doi: 10.18860/mad.v13i2.11343.

[15] H. Baharun, "Pengembangan Media Pembelajaran Pai Berbasis Lingkungan Melalui Model ASSURE," Cendekia J. Educ. Soc., vol. 14, no. 2, p. 231, 2016, doi: 10.21154/cendekia.v14i2.610.

[16] R. Mason and F. Rennie, Elearning: Panduan Lengkap Memahami Dunia Digital dan Internet. Yogyakarta: Baca!, 2010.

[17] F. N. Arifa, "Tantangan Pelaksanaan Kebijakan Belajar Dari Rumah Dalam Masa Darurat Covid19," Info Singkat;Kajian Singk. Terhadap Isu Aktual Dan Strateg., vol. XII, no. 7/I, pp. 13-18, 2020.

[18] H. Hamimah et al., "Thinking the Most Convenient Analysis of Alpha Generation by Using Social Science Story Digital Books," Illkögretim Online, vol. 19, pp. 78-86, Jan. 2020, DOI: 10.17051/ilkonline.2020.654895.

[19] G. P. Yustika, A. Subagyo, and S. Iswati, "Masalah Yang Dihadapi Dunia Pendidikan Dengan Tutorial Online: Sebuah Short Review," Tadbir J. Stud. Manaj. Pendidik., vol. 3, no. 2, p. 195, 2019, doi: 10.29240/jsmp.v3i2.1178.

[20] N. Aldoobie, "ADDIE Model," Am. Int. J. Contemp. Res., vol. 5, no. 6, 2015.

[21] Smaldino, S. E, J. D. Russel, R. Heinich, and M. Molenda, Instructional Technology and Media for Learning. Ohio: Pearson Merrill Prentice Hall,
2008.

[22] N. Moradmand, A. Datta, and G. Oakley, "The Design and Implementation of an Educational Multimedia Mathematics Software : Using ADDIE to Guide Instructional System Design," J. Applied Instr. Des., vol. 4, no. 1, pp. 37-49, 2014.

[23] I. wayan Budiarta, "Pengembangan Multimedia Interaktif Model Addie Untuk Meningkatkan Motivasi Belajar Sejarah Siswa Kelas X-1 Semester Genap Di Sman 1 Sukasada, Buleleng, Bali," J. Pendidik. Sej., vol. 2, no. 1, pp. 1-12, 2014.

[24] R. Gusmida and N. Islami, "The Development of Learning Media for the Kinetic Theory of Gases Using the ADDIE Model with Augmented Reality," J. Educ. Sci., vol. 1, no. 1, p. 1, 2017, doi: 10.31258/jes.1.1.p.1-10.

[25] V. H. Pranatawijaya, W. Widiatry, R. Priskila, and P. B. A. A. Putra, "Pengembangan Aplikasi Kuesioner Survey Berbasis Web Menggunakan Skala Likert dan Guttman Viktor," J. Sains dan Inform., vol. 5, no. 2, pp. 128-137, 2019, doi: 10.34128/jsi.v5i2.185.

[26] Riduwan dan Sunarto, Pengantar Statistika Untuk Penelitian: Pendidikan, Sosial, Ekonomi, Komunikasi, dan Bisnis. Bandung: Alfabeta, 2013. 